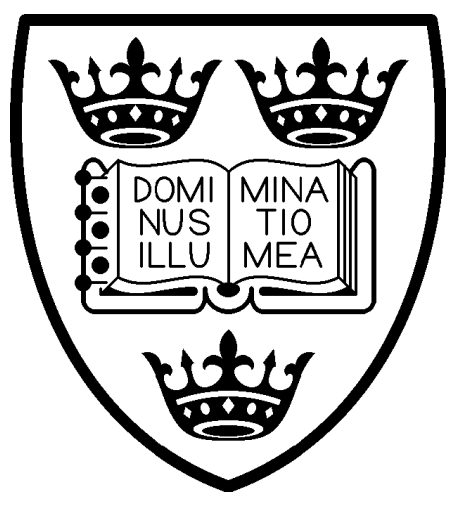

UNIVERSITY OF OXFORD

Discussion Papers in Economic and Social History

Number 75, January 2009

\title{
A CENTURY OF ECONOMIC GROWTH \\ IN LATIN AMERICA \\ Pablo Astorga
}




\title{
A CENTURY OF ECONOMIC GROWTH IN LATIN AMERICA*
}

\author{
Pablo Astorga \\ Senior Economist at Oxford Economics \\ Abbey House, Carfax, Oxford, OX1 1HB, England \\ and \\ Associate Researcher at Instituto Figuerola \\ Universidad Carlos III, C/ Madrid, 126, 28903 Getafe, Madrid España \\ <pastorga1@gmail.com> \\ 98 Sunningwell Road, Oxford, OX1 4SY
}

\begin{abstract}
This paper makes a contribution to the study of economic growth in developing countries by analysing the six largest Latin American economies over 105 years within a two-equation framework. Confirming previous findings, physical and human capital prove to be key determinants of GDP per capita growth. However, a more controversial result is an overall negative conditional correlation between trade openness and GDP per head growth - though openness has a positive link via investment. The evidence also shows that macroeconomic instability has been a drag on long-term growth in the region.
\end{abstract}

JEL classifications: F43; N26; O11

JEL keywords: Economic Growth; Investment; Openness; Latin America

\footnotetext{
* The paper benefited from comments by Valpy FitzGerald, Leandro Prados, Antonio Tena, Leonardo Vera and an anonymous referee. The author also thanks participants to a economic history seminar held at the University Carlos III in Madrid and to the LACEA meeting in Paris for helpful ideas.
} 


\section{Introduction}

The last two decades have witnessed the proliferation of multi-country studies, which, on the one hand, focus on the connection between trade openness and economic growth and, on the other, explore the role of macroeconomic stability in the accumulation of capital. These inter-related themes have been a recurrent concern for both academics and policymakers in Latin America, and are of particular relevance at present when policy debates in the region again centre on whether to join the new wave of globalisation or to pursue a revival of the old inward-looking development strategy. The pro-market reforms of the 1980s and 1990s were instrumental in putting an end to endemic macroeconomic instability, by advancing export diversification and strengthening fiscal and monetary discipline. However, the promise of a new period of high and sustained economic growth in more open and competitive economies has yet to materialise. $^{1}$

The openness debate remains very much alive, particularly after Rodriguez and Rodrik (2001) found in an influential critical study that, despite previous research claims asserting a positive link between openness in trade policy and economic growth based on data from for the second half of the last century, there was little conclusive evidence to support such claims. ${ }^{2}$ For instance, Harrison's (1996) extensive review of empirical work in this area prior to 1992 reports a generally positive association between openness measures and growth but also warns that these results are sensitive to changes in specification (e.g., the inclusion or omission of macroeconomic stability variables) and on the choice of time-aggregation. Meanwhile, in a study concentrating on developing countries during the period 1970-1997 Yanikkaya (2003) shows that there is not a simple and straightforward relationship between openness and economic growth and that it depends on the type of measure used (e.g., trade intensity ratios or trade barriers). Closer to home, De Gregorio (1992) in a work analysing twelve Latin American countries over the period 1950-1985 found that various openness indicators (including the share of trade in GDP) are not significantly related to GDP per capita growth - though macroeconomic stability and human capital played a crucial role.

Widening the scope of the method of analysis to take into account transmission mechanisms via capital accumulation, Baldwin and Seghezza (1996) developed a model and associated estimating equations showing that openness can affect the return on investment by influencing capital's rental rate and the cost of new capital. In a cross-country study over the period 1960-1989 they found that trade barriers depress investment and, through this link, growth, but found no evidence for trade-induced technology-led growth. Adopting also a system equation approach Wacziarg (2001), using panel data over the period 1970-1989, found a strong positive impact of trade policy openness on economic growth, with the accelerated accumulation of physical capital accounting for more than half of its total effect. Smaller effects operated

\footnotetext{
${ }^{1}$ We limit our references to those studies that are more relevant to our aims. For an overview of the economic history of the region in the twentieth century see Thorp (1998).

${ }^{2}$ Rodriguez (2006) looks at the evidence after 1990 reporting a failure to display a robust link between greater trade integration and economic growth.
} 
through enhanced technology and better quality of macroeconomic policy. Meanwhile, Lee (1995) built an endogenous growth model in which the import intensity in the composition of capital increases growth directly by improving its productivity. This prediction is confirmed in a cross-country exercise covering the period 19601985. Lee also found that the import of capital goods, not total imports, is the key factor that links trade to economic growth. ${ }^{3}$

Turning to the connexion between macroeconomic conditions and capital accumulation, a growing literature focusing on developing countries points to the detrimental effect of instability on investment decisions. ${ }^{4}$ For instance, Servén (2003) reports a negative connection between private investment and macroeconomic uncertainty in real exchange rates using a panel data set comprising sixty-one developing countries over the period 1970-1995. Based on a cross-country study covering forty-six countries (including seventeen Latin American countries) over the period 1970-1992, Aizenman and Marion (1999) found a negative correlation between various volatility measures and private investment. However, such correlation was not found in regressions using total investment as the dependent variable.

The majority of this empirical work (whether based on cross-country or panel data sets) uses data covering a relatively short span of time, usually 30 years or so after 1960 , and in general tends to be dominated by the period of unprecedented growth in the global economy and, in the Latin American case, by the decades of import substitution, the 1980s debt crisis and its aftermath. ${ }^{5}$ Though the choice of period is largely dictated by data availability - particularly when attempts are made to include a large sample of developing countries - it raises questions as to whether this time span is adequate to capture long-term effects, and whether what is true for the late twentieth century is also true for early periods. In order to address this shortcoming, Vamvakidis (2002) looked at the historical evidence from 1870 to the present, and found no support for a positive growth-openness connection before 1970 - though he largely uses average tariff rates as policy proxy, while cross-country results for the post-war period suggest that the positive correlation between openness and growth is only a recent phenomenon. Moreover, the correlation between tariffs and growth was positive for the interwar period. O'Rourke (2000) also found a positive correlation between tariff protection and growth in ten now-developed countries in the period 18751914.

Continuing in this line of enquiry, this paper offers a new look at the determinants of long term growth in Latin America with special emphasis on the role of physical and human capital, trade openness and macroeconomic stability. Our econometric work has two novelties. First, it benefits from a new long-term data base for the re-

\footnotetext{
${ }^{3}$ His regression results show that the coefficient of the share of imports on GDP loses its significance when the ratio of imported to domestically-produced investment is included.

${ }^{4}$ In theory, uncertainty can undermine investment when adjustment costs are asymmetric and hence decisions are irreversible (Dixit \& Pindyck, 1994). However, the relationship depends on what is assumed about attitudes to risk and market structure (Caballero, 1991).

${ }^{5}$ For instance, of the twenty-four empirical studies reported in Harrison (1996), none of them covers the period prior to 1950, and their average period length is about three decades. More recent works incorporate data from the $1990 \mathrm{~s}$, but still are subject to a similar criticism.
} 
gion which makes it possible to construct a rich panel data set including more than twenty growth determinants over the period 1900-2004 for the six largest economies in the continent, namely Argentina, Brazil, Chile, Colombia, Mexico and Venezuela (or LA-6). ${ }^{6}$ This has the advantage that important changes in economic policy over time, as well as the impact of periods of increased macroeconomic instability, can be properly taken into account. Secondly, we use a two-equation system to estimate jointly economic growth and investment, while controlling for trade openness and other drivers, moving away from single-equation estimation. We report three main findings. First, that the accumulation of physical (and its embodied technology) and human capital have been key drivers of long-term growth. Secondly, and more controversially, we find an overall negative conditional correlation between trade openness and GDP per head growth - though openness has a positive connection through investment. Thirdly, we find that macroeconomic instability has been a major drag on economic growth in the region.

The rest of the paper is organised as follows. Section 2 introduces the empirical specification. Section 3 presents the econometric outcome. Section 4 tests for additional growth factors and discusses their implications for the openness contribution. Section 5 offers a robustness analysis. The paper ends with a section of conclusions. In addition, Annex A reports detailed regression results and Annex B describes data sources.

\footnotetext{
${ }^{6}$ The Oxford Latin American Economic History Database, OxLAD. We also draw from recently compiled historical country data bases for Brazil (IBGE, 2003, and IPEA), Chile (Díaz et al., 2005), and Colombia (GRECO, 2002). The group of countries examined here accounts for about $3 / 4$ of the regional GDP and population over the century, which makes it highly representative of the continent as a whole. Reliable series on key variables such as GDP and investment for most of the $\mathrm{XX}^{\text {th }}$ century are not available for a wider sample of countries - perhaps with the exception of Uruguay.
} 


\section{Empirical Specification}

Baldwin and Seghezza (1996) - hereinafter B\&S - give a sound theoretical anchor for our empirical work. The main contribution of $\mathrm{B} \& \mathrm{~S}$ lies in providing testable equations that are explicitly derived from a theoretical model capturing the joint determination of economic growth and physical capital while controlling for trade barriers. ${ }^{7}$ The key transmission mechanism works via the demand for capital. Domestic protection creates conflicting influences on the steady state position of the investment ratio. On the one hand, trade barriers tend to raise the rental rate of capital, inducing higher investment. On the other, protection discourages investment by raising the cost of new capital goods, since trade goods are an intermediate input into the production of new capital. The net impact on growth via investment is ambiguous, with the possibility of trade-induced, investment-led growth if the latter effect dominates. After stating the preferences of a representative consumer the model is solved as a two-stage utility maximisation problem and the following system of estimating equations derived:

$$
\begin{aligned}
& y_{j}=c_{11}-c_{12} Y_{j 0}-c_{13} p_{j}+c_{14} I_{j}+c_{15} H_{j 0}+e_{1 j} \\
& I_{j}=c_{21}-c_{22} \log Y_{j 0}+c_{23} \log H_{j 0}-b_{2} T d_{j}-b_{2} T f_{j}+e_{2 j}
\end{aligned}
$$

Where, for country $j, y_{j}$ stands for the growth rate of GDP per capita, $I_{j}$ is the ratio of investment to GDP, $Y_{j 0}$ is the initial level of GDP per capita, $p_{j}$ is population growth, $H_{j 0}$ refers to variables accounting for human capital formation (the secondary school enrolment and attainment rates), and $T d_{j}$ and $T f_{j}$ stand for domestic and foreign trade barriers respectively.

We adapt the B\&S specification by introducing the following changes:

(i) the use of the average gross share of international trade (i.e., $O_{t}=\left[X_{t}\right.$ $\left.\left.+M_{t}\right) / 2 * G D P_{t}\right]$ as the openness variable rather than trade barriers, so our results cannot provide firm conclusions regarding the effects of trade policy. Also we do not include measures of foreign openness;

(ii) to exploit the advantages of our panel setting we include the lagged investment ratio in the investment equation as well as a lagged value of GDP growth - the acceleration principle - adding a Keynesian flavour to the specification;

(iii) the addition of a set of variables to account for macroeconomic stability and structural and institutional change (but also present in regressions 1 in Annex A results that only include the B\&S variables);

(iv) regarding the functional form, variables in the growth equation are expressed in log terms to facilitate the interpretation of the estimated coefficients and comparisons with the outcome of related research. ${ }^{8}$

\footnotetext{
${ }^{7} \mathrm{~B} \& \mathrm{~S}$ focus on intra-industry trade - though the authors extend their empirical testing to a sample of developing countries. Although foreign trade in the LA-6 was dominated by commodities during most of the last century, increased trade integration in the region has brought about a bigger role for intraindustry trade in recent decades.

${ }^{8}$ The comparison between regressions using the original B\&S functional form and that using logs shows little differences in the significance of the coefficients.
} 


\subsection{Structural system}

Our empirical model consists of a system of two equations:

Growth equation:

(1) $y_{t}=a_{o}+a_{1} I_{t}+a_{2} O_{t}+a_{3} Y_{t 0}+a_{4} p_{t-1}+a_{5} H_{t-1}+\sum a_{j} V_{i, t}+e_{1 t}$

Investment equation:

(2) $I_{t}=b_{o}+b_{1} I_{t-1}+b_{2} O_{t}+b_{3} z_{t-1}+b_{4} p_{t-1}+b_{5} H_{t-1}+\sum b_{j} W_{i, t}+e_{2 t}$

where $y_{t}$ stands for the annualised rate of growth of GDP per head, ${ }^{9} I_{t}$ is the average ratio of investment to GDP as a proxy for fixed capital accumulation, $O_{t}$ is our openness measure, $Y_{t 0}$ is the log level of GDP per head at the start of the period, $p_{t-1}$ is the annualised rate of growth of the population lagged one period, $H_{t-1}$ refers to variables accounting for human capital formation (i.e., life expectancy and illiteracy levels). $V_{i, t}$ stands for a set of variables accounting for macroeconomic stability, structural and institutional changes, and dummy variables. Meanwhile, in (2), $I_{t-l}$ is the lagged value of the investment ratio, $\mathrm{z}_{t-1}$ stands for the lagged growth of GDP - to account for the accelerator principle - and, as before, $W_{i, t}$ includes a set of variables accounting for additional factors and dummies.

As in B\&S, the only variable treated as endogenous in the growth equation is $I_{t}$. Potential endogeneity between both openness and growth and openness and investment are addressed by using instrumental variables (IV). ${ }^{10}$ The openness variable is included in the growth equation to test for any direct effect (e.g., via technology transmissions or efficiency gains) after controlling for physical and human capital, as well as in the investment equation to test its indirect contribution via capital accumulation. Finally, also in line with B\&S, human capital formation is assumed to be a policy choice and enters the equation as a predetermined variable which help to minimise problems of reverse causation.

The expected signs for the individual coefficients in (1) and (2) are as follows: $a_{1}>0 ; b_{1}>0 ; a_{2}<>>0 ; b_{2}<>>0 ; a_{3}<0 ; b_{3}>0 ; a_{4}<>>0 ; b_{4}>0 ; a_{5}>0 ; b_{5}>0$

The association between investment and growth in (1) is expected to be positive, as well as the link between present and lagged investment in (2). Also, lagged GDP growth is to be positively related to investment. Meanwhile, the coefficient of $Y_{t 0}$ is expected to be negative, reflecting a process of intra-regional convergence.

Regarding openness, the sign of $a_{2}$ in (1) is ambiguous. In addition to the traditional static efficiency gains generated by comparative advantages, endogenous growth models emphasise technological spillovers and the international transmission of knowledge as a source of growth for open economies (Grossman \& Helpman, 1990). However, protection might also boost higher longer-term growth in those cases

\footnotetext{
${ }^{9}$ We divide GDP by the economically active population. Note that we use "per head" to make a distinction between this measure and GDP per capita or GDP per worker. Because all three variables tend to be highly correlated, $y_{t}$ can be a proxy for growth in both labour productivity and income per capita.

${ }^{10}$ There are various ways in which the trade share may be endogenous, for instance by being related to income rises so that countries whose incomes are high for reasons other than trade may trade more (Frankel \& Romer, 1999), and in the investment equation by including imports demanded by investment projects.
} 
where it encourages learning by doing, as proposed by the infant industry argument (Corden, 1974, chap. 9) and/or investment in research-intensive sectors. Equally, the sign of $b_{2}$ in (2) is undetermined, for instance, owing to the conflicting effects of $O_{t}$ on the demand for new capital as in B\&S. Also, investment may respond positively to trade openness via market size effects, where more open economies are in a better position to exploit increasing returns to scale; but a negative link can result when a move towards trade liberalisation increases competition and lowers profits, which, in turn, discourages investment.

As to the coefficients associated with $p_{t-1}$, the sign of $a_{4}$ in (1) is ambiguous. Population growth can play a positive role if associated with higher net immigration or lower mortality (Barro \& Sala-i-Martín, 1995), but it can also depress growth per head by raising the dependency ratio, or if the economy is not able to absorb the expansion in the labour market. Meanwhile, $b_{4}$ in (2) is likely to be positive as an expanding population can stimulate investment by increasing the market size. Finally, the coefficients associated with human capital $\left(a_{5}\right.$ and $\left.b_{5}\right)$ are expected to be positive.

Of special importance for this work is the link between $O_{t}$ and $y_{t}$, both directly and, indirectly, via capital accumulation. By substituting (2) into (1) it results in:

(3) $y_{t}=\left(a_{o}+a_{1} b_{o}\right)+a_{1} b_{1} I_{t-1}+\left(a_{1} b_{2}+a_{2}\right) O_{t}+a_{3} Y_{t-1}+a_{1} b_{3} z_{t-1}+$

$$
\left(a_{4}+a_{1} b_{4}\right) p_{t-1}+\left(a_{5}+a_{1} b_{5}\right) H_{t-1}+\sum a_{j} V_{i, t}+\sum a_{1} b_{j} W_{i, t}+a_{1} e_{2 t}+e_{1 t}
$$

And by partial differentiating with respect to $O_{t}$ :

(4) $\partial y_{t}^{2} / \partial O_{t}=a_{1} b_{2}+a_{2}$

The first term measures the impact of openness via capital accumulation, whilst the second essentially accounts for its influence on total factor productivity since the contribution of investment and human capital is controlled directly. The sign of both terms is undetermined, so the net effect is ambiguous and needs to be tested empirically. This is done in Section 3.

\subsection{Core and augmented specifications}

Our estimation strategy is to begin by testing specifications that include only the core factors in B\&S (i.e., standard regressors plus human capital), and then move to augmented specifications where we can assess the role of a number of additional factors commonly found in the empirical literature discussed above, such as macroeconomic stability and structural transformations. These specifications tend to include only those determinants that were significant in more encompassing regressions. ${ }^{11}$

Human capital is measured by the illiteracy rate (in logs) lagged ten years (lil$\left.l i t_{t 2}\right) ;^{12}$ and the annualised growth of life expectancy during the previous period (d2life). ${ }^{13}$ The latter also reflects human capital (via health conditions) and should

\footnotetext{
${ }^{11}$ We initially tested the additional factors in both equations in cases where there were reasons to believe that they could have an impact on investment decisions as well as on long-term growth.

${ }^{12}$ The use of available series of attainment rate (the share of the population with secondary education) led to similar results, though we opted for literacy because there are better data in the first half on the century. The correlation between both variables is -0.83 .

${ }^{13}$ GDP per head, life expectancy and, to a lesser extent, the illiteracy rate and the share of agriculture in GDP, tend to be highly correlated. To avoid problems of multicolinearity we use average growth rates
} 
capture some of the effects of structural changes (e.g., urbanisation). Structural and institutional transformations are measured by the agriculture share of GDP (agrish) an inverse proxy for industrialisation - and the share of customs taxes on fiscal revenues (cutaxsh) to capture institutional development or 'governance'. Also included in the investment equation is the average annual growth of the income terms of trade (ITTg) as a proxy for the effect of natural resources - via commodity exports.

The set of macro stability variables includes the growth rate of the terms of trade (NBTTg), which may have an enduring effect on growth, though the sign of the effect is ambiguous (Barro \& Sala-i-Martín, 1995). It can also reflect the profitability of investment projects. The average US real interest rate (USrirate) is added in (2) as a proxy for capital flows. Meanwhile, the effect of inflation (assumed to be exogenously determined) on economic activity is captured by the standard deviation of the CPI growth rate $(I N F s d)$ - a measure of its predictability. ${ }^{14}$ The potential instability originating in lack of fiscal discipline is measured by the average ratio of the budget surplus to GDP (GBSHavg). Moreover, two measures are constructed to account for relative price uncertainty: the volatility in the net barter terms of trade (NBTTsd) and in the real effective exchange rate (REERsd), both obtained as the standard deviation of growth rates during each period. Finally, dummy variables are included to account for the impact of major external shocks such as the two World Wars (WWI and WWII) and the debt crises of the 1980s (DEBT80), as well as country-specific events (e.g., the Mexican revolution, and the transformation of Venezuela into an oil economy in the early 1920s).

Regarding potential omitted variables, the absence of long-term data and measurement difficulties mean we can only give a limited coverage to other potentially relevant variables such as political instability (Stasavage, 2000) and natural resource availability. In some cases, dummy variables are used to account for major episodes of social and political disruption. As to the contribution of natural resources, commonly used measures such as cultivated-land area are inadequate to account for the discovery of minerals - a crucial factor in Mexico, Venezuela and Chile. To some extent the resource effect is incorporated in the initial level of GDP per head. Finally, neoclassical determinants of capital accumulation such as real interest rates and the cost of capital are difficult to include owing to data limitations. However, in those countries where the data are available for most of the last century they show poor levels of significance in explaining the investment ratio in annual models at a country level. $^{15}$

or changes per period when including life expectancy together with variables associated with structural transformations.

${ }^{14}$ Its inclusion is justified by a number of empirical studies that found evidence that inflation and its variability is associated with low productivity growth (e.g., De Gregorio, 1992) or that high and moderate inflation rates can have a temporary negative growth impact (Andrés \& Hernando, 1997). Causality is still an open question (Bruno \& Easterly, 1998), but in our case there are no good instruments at hand. Volatility values above 100 are capped in order to avoid convergence problems.

${ }^{15}$ E.g., the cost of capital in Brazil and Venezuela proxied by the ratio of the investment and GDP deflators, or real interest rates in Argentina and Colombia. Results are available on request. 


\section{Econometric Outcome}

Our empirical work uses a panel data set covering the period 1900-2004. The major advantage of using panel data versus a cross-section based on averages of several decades is that important changes in economic policy over time as well as the impact of periods of increased macroeconomic instability can be properly taken into account. ${ }^{16}$ Tables in Annex A present the detailed outcome of regressions, including the estimated coefficients and their respective t-values for the explanatory variables in the core and augmented specifications. We report the outcome of two estimation methods: Three-Stage Least Squares (3SLS) and Seemingly-Unrelated Regression (SUR). ${ }^{17}$

In the remainder of this section we discuss results based on the augmented specification estimated with 3SLS using a five-year panel and random effects (regressions $2 a$ and $2 b$ ). This time span can better account for the implications of macroeconomic volatility and reflect lagged effects. However, it may still be influenced by the business cycle and other shorter term effects, undermining its capacity to reveal long-term links between the key variables. ${ }^{18}$ In order to explore the effect of different time periods on the outcome we also estimate the system with ten-year panels (regressions 12 to 15 ) and comment on the results in the robustness section.

Table 1 summarises key results related to the impact on growth, both directly and indirectly through the investment channels. To deal with endogeneity issues in the openness variable we use as instruments the lagged value of the trade ratio, population (in logs) as a gravity factor, ${ }^{19}$ and an index measuring global freight real costs. ${ }^{20}$ Other left hand size variables are instrumented by themselves.

The first two columns include the units of the variables and their standard deviations. Columns 2 and 3 report the estimated coefficients of the growth and investment equations respectively. The overall effect on growth per head is calculated in column 4 taking into account the direct and indirect effects - if any. The latter result from multiplying the coefficient associated with a particular variable in the investment equation by the coefficient of $I_{t}$ in the growth equation. Finally, column 5 quantifies the growth impact calculated as the product between one standard deviation change of a given regressor and its overall effect. These impacts are measured in percentage

\footnotetext{
${ }^{16}$ For instance, Harrison (1996) found that the statistical significance of the coefficient of various openness indicators improves in growth regressions with panel data with five-year averages compared to those results obtained when cross-section data are employed.

${ }^{17}$ The SUR technique estimates the parameters of the system accounting for contemporaneous correlation in the errors across equations, with all determinants assumed to be exogenous. 3STS is the appropriate estimation method when right-hand side variables are correlated with the error term and there is contemporaneous correlation in the residuals.

${ }^{18}$ For instance, Rodiguez and Rodrik (2001) suggest the use of ten-year panel data to test the long-run connection between openness and economic growth.

${ }^{19} \mathrm{We}$ do not include land area as it can be misleading in reflecting market size owing to the existence of large unpopulated areas in the LA-6.

${ }^{20}$ Although openness is serially correlated the error terms of the SUR regressions show low level of first-order autocorrelation (under 0.2) which gives some validity to the selected instruments.
} 


\begin{tabular}{|c|c|c|c|c|c|c|c|}
\hline \multicolumn{8}{|c|}{$\begin{array}{c}\text { Table 1: Main Determinants of Economic Growth } \\
\text { Based on } 3 S L S \text { with 5-year panel }\end{array}$} \\
\hline \multicolumn{4}{|c|}{ var. information } & \multicolumn{4}{|c|}{ effects on growth of GDP per head $\left(y_{t}\right)$} \\
\hline description and na & & units & $\begin{array}{c}\text { st dev } \\
(1)\end{array}$ & $\begin{array}{c}\text { Direct } \\
(2)\end{array}$ & $\begin{array}{l}\text { Indirect } \\
(3)\end{array}$ & $\begin{array}{c}\text { Overall } \\
(4)=(2)+(3)^{*} I_{t} \text { dir }\end{array}$ & $\begin{array}{l}\text { Impact } \\
(5)=(1)^{*}(4)\end{array}$ \\
\hline Investment & $I_{t}$ & $\% G D P$ & 5.5 & 0.13 & & 0.13 & 0.72 \\
\hline Openness & $O_{t}$ & $\% G D P$ & 8.3 & -0.05 & 0.18 & -0.03 & -0.25 \\
\hline Terms of trade & NBTTg & growth & 6.8 & -0.02 & & -0.02 & -0.13 \\
\hline Life expectancy lagged & d2life & growth & 0.7 & 1.13 & & 1.13 & 0.78 \\
\hline Illiteracy rate lagged & lillit $_{t-2}$ & logs & 0.9 & -0.70 & & -0.70 & -0.63 \\
\hline GDP lagged & $z_{t-1}$ & growth & 2.8 & & 0.78 & 0.10 & 0.28 \\
\hline Income terms of trade & $I T T g$ & growth & 11.9 & & 0.11 & 0.01 & 0.17 \\
\hline \multicolumn{8}{|l|}{ Macro stability } \\
\hline Inflation & INFsd & st dev & 30.3 & $\underline{-0.01}$ & & -0.01 & -0.29 \\
\hline Terms of trade & NBTTsd & st dev & 9.7 & & -0.09 & -0.01 & -0.11 \\
\hline Real exchange rate & REERsd & st dev & 10.2 & -0.04 & -0.04 & -0.05 & -0.48 \\
\hline
\end{tabular}

points per year (\%pts). For instance, our results show that one standard deviation in $I_{t}$ (5.5) would bring about a $0.72 \%$ pts rise in $y_{t}$. In terms of levels, this means that, had the LA-6 countries sustained a higher investment effort equivalent to an investment ratio of $22.3 \%$ rather than the historical average value of $17.7 \%$ since 1900 , income per capita would have been over two-fold higher by $2000 .^{21}$

Meanwhile, the overall effect of openness $(-0.03)$ in column 4 means that one standard deviation change in $O_{t}$ would bring about a decline of $0.25 \%$ pts in growth of GDP per head. This is the result of adding up two effects of opposite signs (from equation 4): one positive, operating through the investment channel $\left(0.18^{*} 0.13\right)$; and one negative, acting directly in the growth equation $(-0.05)$. The fact that openness was a major determinant of investment and, in turn, that investment had a positive direct contribution to economic growth (trade-induced investment-led growth) indicates that factors such as the cost of new capital, technological innovations and market size boosted growth in the medium to longer term. The negative sign of the openness coefficient in the growth regression suggests that mechanisms such as learning by doing brought about by protectionist policies - outweighing static efficiencies - may have played a positive role in supporting economic growth. At the same time, it raises doubts about the strength of other channels such as improved resource allocation and technology transmissions associated with openness to international trade, though these may be reflected in the residual term. ${ }^{22}$

\footnotetext{
${ }^{21}$ This is still a relatively modest investment ratio for a developing economy. The average investment ratio for East-Asia countries during 1973-1997 was 30\% (Maddison, 2001) compared to $20 \%$ in the LA-6.

${ }^{22}$ The typical adjusted- $\mathrm{R}^{2}$ of our growth regressions is 0.7 , so about $30 \%$ of changes in long-term growth are still unexplained.
} 
Other effects are associated with the accelerator principle and life expectancy. The estimation of the equation system gives a significant correlation $(0.78)$ between $\mathrm{z}_{t-1}$ and $I_{t}$. Once this effect feeds through investment into the growth equation, its impact in the following period (five years) is calculated as a $0.28 \%$ pts rise per one-standard deviation change. Meanwhile, changes in life expectancy (d2life) have the potential to add $0.78 \%$ pts to GDP growth per head. ${ }^{23}$ The life expectancy variable is likely to reflect other contributing factors of long-term growth, such as the accumulation of human capital and structural and institutional changes. The coefficient associated with lillit $_{t 2}$ is also significant and negative $(-0.70)$, confirming the contribution of advances in basic education. Also, there is a positive and significant link between $I_{t}$. and ITTg. As expected, improved income terms of trade have a positive effect on external and fiscal accounts, boosting funding for investment projects.

Regarding measures of macro economic instability and policy uncertainty, we found that volatility in CPI inflation and in the real exchange rate had a significant negative direct impact on GDP per head growth. Our calculations show that one standard deviation in $I N F s d$ could have resulted in a $0.29 \%$ pts fall in growth per year and by $0.48 \%$ pts in the case of REERsd. Meanwhile, unpredictability in the terms of trade has an associated negative growth impact (via investment) of $-0.11 \%$ pts.

Other variables capturing macroeconomic conditions, such as the budget surplus and foreign exchange premia (reflecting economic distortions brought about by exchange controls), proved not to be significance in the five-year panel and are consequently omitted from Table $1 .^{24}$ Also insignificant were agrish and cutaxsh, which were dropped from the reported regressions. However, this may be partly owing to the fact that both variables are strongly correlated with GDP per capita and life expectancy which weakens their significance when included in the same regression. To test for this possibility we run additional regressions (not shown) using lagged changes in both variables in (1) instead of d2life but they failed to be significant and little altered the growth role of $O_{t}$. However, this should not be taken as conclusive evidence against potential growth effects arising from resource re-allocation or institutional improvements, as both variables, particularly cutaxsh, are imperfect measures for industrialisation and governance. For instance, in the case of institutional development, Bosworth and Collins (2003) report a high correlation between growth and the quality of government institutions - especially for developing countries - in their comprehensive cross-country study.

Other results shown in regression 2 are consistent with many previous studies of conditional convergence and indicate that growth per head is negatively correlated with the initial level of GDP per head. The coefficient means that there was a process of regional convergence of labour productivity in the six Latin American economies on the order of $1.3 \%$ per year. Meanwhile, the US real interest rate has the expected

\footnotetext{
${ }^{23}$ This result is consistent with findings by Barro and Sala-i-Martín (1995) of a strong, positive relation between life expectancy and GDP per-capita growth, which is explained by the health component of human capital.

${ }^{24}$ This indicates that there are no lasting growth effects when both annual variables are averaged out over the period. However, there is a potential endogeneity problem between these two factors and growth, but unfortunately no satisfactory instruments are available.
} 
negative sign and is significant, confirming the importance of developments in foreign capital markets for the funding of investment. And the dummy variable accounting for the debt crisis confirms that it had severe consequences for the region's living standards. The estimated coefficient implies that it reduced per head growth by $3.3 \%$ pts during the period $1980-1985 .^{25}$ In other circumstances the region would have achieved growth of income per capita of about $1 \%$ during the period, ceteris paribus, and would have avoided a level fall of about $20 \%$. The war dummies indicate that the disruption caused by the Great War had a negative impact on growth $(2.2 \%$ pts decline in growth) and that the Second World War was particularly harmful to investment, resulting in an average fall of about 6 points in $I_{t}$ during the period.

The adjusted- $\mathrm{R}^{2}$ for the growth equation $(0.72)$ and for the investment equation (0.56) suggests that the system has good explanatory power. The level of first-order autocorrelation in the residuals is low, indicating that there are no apparent problems of serial correlation. Also, in both residual series the unit root hypothesis is rejected (using the augmented Dickey-Fuller test)) and the Jarque-Bera test does not reject the assumption of normality (results not shown). Meanwhile, stability tests perform on the reduced-form regressions (16a and 16b)) show that both CUSUM and CUSUM of squares tests lie within the $5 \%$ critical lines and that there are no major apparent problems of parameter stability in the recursive coefficient estimates. ${ }^{26}$

\footnotetext{
${ }^{25}$ Over the "lost decade" the growth loss was a lower 2.2\%pts per year (regression $13 a$ ).

${ }^{26}$ We use EViews5 for the regression analysis. In this package stability tests are only available for single regressions estimated under ordinary least squares, so these tests can not be perform on the structural system.
} 


\section{Extensions}

Although the trade share is a commonly used measure of openness, it has the disadvantage that it does not distinguish between policy and non-policy related factors of trade integration in which changes have potentially different growth effects. For instance, the trade share growth role can be affected by shifts in the terms of trade (Birdsall and Hamoudi, 2002) or by the degree of export diversification. In this section we control for some of these factors and assess the implications for the openness contribution. In addition, this offers a test for the possibility of omitted variables in the results presented previously.

\subsection{Protection and resource re-allocation}

One finding in particular that needs further investigation is the negative link between $O_{t}$ and $y_{t}$. In terms of the economics underlying this result, two traditional hypotheses are based on learning effects and the structural impact of protection (O'Rourke, 2000). The first is associated with the infant industry argument, whilst the second is the consequence of the shift of resources from agriculture into sectors with higher productivity potential (e.g., manufacturing) as in the classical Kuznets-Lewis model. The main problem in testing for policy-related factors is the lack of appropriate indicators quantifying developments in trade policy over the century in the LA-6. What are available are series of average tariffs (i.e., custom duties as a share of total import value), but this measure has well-known shortcomings (Pritchett \& Sethi, 1994) and has only a limited use for the LA-6 - particularly those after 1940 or so. ${ }^{27}$

High tariffs (relative to international levels) were imposed in the LA-6 in the early decades of the last century primarily intended to produce revenue, though they also offered some protection for infant industries particularly in the larger economies (Coatsworth \& Williamson, 2002). For the LA-6 as a group, the correlation between average tariffs and $O_{t}$ is positive (0.39) during the period of 1900-1930. This is likely to be the result of higher commodity exports outweighing the effect of protection on imports. By contrast, the barriers implemented during the middle period (a combination of tariffs, quotas and multiple exchanges rates) were largely part of a strategy of import substitution with a strong State involvement (ISI) aimed at developing and expanding an indigenous manufacturing base. By that time, most fiscal revenues were raised through direct taxation or duties and royalties imposed on the export of commodities. This period is certainly one of low trade openness and high protection, a fact that series of average tariff fail to capture.

The 1980s and 1990s saw a general move towards trade liberalisation - resulting in higher trade openness - supported by the creation of MERCOSUR in 1991 and Mexico joining NAFTA at the end of 1994. However, in general, the ISI - though successful in developing infrastructure and industry - did not give rise to an efficient manufacturing sector. This placed many industries in a vulnerable position at a time when they were exposed to foreign competition, in many cases setting in motion a

\footnotetext{
${ }^{27}$ For instance, it fails to take into account the price elasticity of imports, does not reflect the impact of other policy barriers and, in the LA-6 case, it is subject to measuring problems in those countries that suffered hyperinflation.
} 
process of industrial restructuring. ${ }^{28}$ The latter is likely to weaken the potentially positive link between openness (to the extent that it reflects trade liberalisation) and growth during those years.

Given the region's history of trade policy, any growth benefits emanating from learning effects should be particularly felt during the ISI period (roughly 1935-1979). Thus, the comparison between results over the whole period (regressions 2) with those of the ISI years (regressions 8) could give some indication of the relevance of learning by doing in accounting for per head growth. The coefficient of $O_{t}$ in regression 8 a doubles in the ISI period $(-0.10$ from -0.05$)$ and its significance gets stronger. Although this is far from being hard evidence that infant-industry protection boosted growth - despite its efficiency costs, ${ }^{29}$ it sheds some light on the likely sources behind the negative coefficient of openness. Moreover, this result is consistent with microeconomic studies of technological learning showing that observed productivity increases in manufacturing during the ISI period came from efforts associated with improving product design, production engineering and organisation of labour (Katz \& Kosacoff, 2000).

Regarding the productivity implications of industrialisation, the correlation between $O_{t}$ and $d 2$ agri is -0.12 for the whole period and -0.21 between 1935 and 1979, indicating a moderate link between protection and structural change. However, when included in regression 8a, d2agri is not significant and has little impact on openness, though it lowers the contribution of life expectancy. This apparent weak growth impact is consistent with evidence in Astorga et al. (2003) showing that inter-sectoral labour reallocation was not the main source of productivity growth in the LA-6 during the twentieth century, with the possible exception of Chile.

\subsection{Export diversification}

The interpretation of openness indicator is complicated further by changes in the composition and complexity of the export sector over the last century. Thus, similar values for $O_{t}$ can reflect different structural conditions with direct implications for its contribution to growth. For instance, cases of high openness with high export diversification - particularly into manufacturing - should have a greater positive impact of GDP growth owing to richer linkages and lower external volatility; while high openness in the context of specialisation in the production of primary products is expected to be harmful to long-term growth (Sachs \& Warner, 1997). In the LA-6 the early decades of the last century were driven by the export of commodities by economies with a relatively underdeveloped industrial base. The commodity lottery was the main cause of differences between the countries' fortunes with their growth engine. By contrast, the trade liberalisation drive of the later period took place in economies with a relatively developed industrial sector built during the ISI years.

\footnotetext{
${ }^{28}$ The share of manufacturing value-added in GDP fell in all six countries except Mexico in the last two decades of the last century.

${ }^{29}$ Taylor (1998) discuses the economic distortions generated by the ISI in the region - though he also acknowledge growth benefits from an increased rate of investment - and the underperforming of such strategy in terms of economic growth relative to the experience of those East Asian economies which adopted an outward-looking strategy.
} 
To account for export diversification we construct an index, $X D_{t}$, and add it to both the growth and investment equations. ${ }^{30}$ While one might expect to find a positive correlation for $X D_{t}$ in (1), the sign of the coefficient in (2) is less clear, as resource extraction in commodity exporters usually entails considerable investment. In addition, we adjust the original openness variable by changes in export composition over the century, so that $O^{\prime}{ }_{t}=\left[\left(X_{t} * X D_{t}+M_{t}\right) / 2 * G D P_{t}\right]$, and test the implications. The export diversification index is not significant and its inclusion does not affect the strength of the openness coefficient or the investment ratio (results not shown). However, when $O_{t}^{\prime}$ is used its coefficient is only marginally significant at the $10 \%$ level in the growth equation, whilst remaining broadly unchanged in the investment equation (regressions 9). Therefore, the second result provides some evidence that the degree of export diversification influences the growth impact of $O_{t}$. And it is likely that were $X D_{t}$ to fully reflect the extent of the diversification into manufacturing it would have a stronger positive growth effect. ${ }^{31}$

\subsection{Resource endowment}

Our openness measure also reflects the exploitation of natural resources or the occurrence of commodity windfalls, as they translate into higher exports and increased import capacity. Natural resource discoveries have played a crucial role in expanding economic possibilities in the region and in attracting investment, both foreign and local. Equally, resource-related windfalls have been instrumental in improving fiscal and external positions and in funding public investment. However, in theory, they can also bring about a sustained appreciation of the real exchange rate with negative longer-term consequences for GDP growth via a decline in the production of tradable goods, or 'Dutch disease' (Corden \& Neary, 1982). If this effect dominates, the association between openness and economic growth can be negative.

To capture some of the consequences of resource discoveries or resource windfalls on $y_{t}$, particularly those that can have a lasting impact on economic efficiency and resource allocation, we test for the impact of lagged growth of the real effective exchange rate $\left(R E E R g_{t-1}\right.$, with a rise meaning real depreciation) ${ }^{32}$ Regression 10 indicates that there is a significant positive link between both variables, after controlling for other factors. Taking into account this effect weakens the significance of $O_{t}$ and reduces the size of its contribution, suggesting that part of the negative association of trade and growth may be due to forces linked to resource endowment.

\footnotetext{
${ }^{30}$ The index is the inverse of the ratio of the export of the main two commodities on each country's total exports. It takes the value of zero for mono-export economies and of one for a well-diversified export sector.

${ }^{31}$ The principal two commodities represented $51 \%$ of export sales of the LA- 6 in the period 1900 1930 , ranging from Argentina with $29 \%$ to Chile with $62 \%$. The average share came down to $36 \%$ during the last two decades, ranging from $12 \%$ in Brazil to $81 \%$ in Venezuela. And more detailed data available for the late period show that the share of durables manufacturing on total export value rose from $21 \%$ in 1980 to $36 \%$ in 2000 in Argentina, from $37 \%$ to $63 \%$ in Brazil, and from $17 \%$ to $78 \%$ in Mexico (ECLAC).

${ }^{32}$ The use of the lag makes sense economically as this is a longer-term effect. It also makes the regressor predetermined, avoiding potential problems of endogeneity.
} 


\subsection{Capital import intensity}

Finally, we assess the growth role of the intensity in the use of imports of capital goods in the composition of total investment. Following Lee (1995) we add in (1) the lagged average ratio of imported to domestically-produced capital goods (MKratio ${ }_{t-1}$ ). If foreign trade benefits growth mainly by providing access to cheaper imported capital goods, the inclusion of the ratio should undermine the strength of the growth role of openness. Owing to data limitations we can only test this hypothesis for the postWWII period. Regression 11 shows that MKratio $_{t-1}$ lacks significance and that its inclusion leaves the estimation of the growth equation roughly unchanged (comparing regressions 11 and 3a). The outcome is broadly similar when the import share of GDP $\left(M_{t} / G D P_{t}\right)$ is used rather than the trade share (not shown). This evidence implies that the significance of $O_{t}$ is robust to potential productivity gains associated with the intensity of the use of capital imports in investment. Moreover, it suggests that the growth benefits associated with embodied technology are largely picked up by the investment ratio and not left to the residual. 


\section{Robustness Analysis}

In general, the comparison between the core and the augmented regressions ( 1 vs. 2 for five-year panel and 12 vs. 13 for ten-year panel) shows that the estimation of key coefficients associated with the investment ratio, human capital and trade openness are robust to the inclusion of additional variables accounting for macroeconomic stability and structural and institutional changes. Equally, our main results are robust to the inclusion of fixed-country effects (regressions 2 vs.5 for a five-year panel, and 13 vs.15 for a ten-year panel), though the investment role tends to be stronger when country dummies are added. This means that given the relatively small sample, results are not driven by structural features of some of the economies involved. We also control for country size by including population and for changes in the definition of the trade ratio by using the import share of GDP, with no major impact on the outcome (results not shown).

Regarding the choice of estimation technique, the comparison between 3SLS and SUR outcomes (regressions 2 to 3 vs. 6 to 7 respectively) provides information to evaluate potential misspecification problems when estimating the system simultaneously. Broadly speaking, there is little change in terms of the level of significance of the coefficients, indicating that the estimation of the system is robust to the choice of technique and that there is no apparent risk that a poorly specified investment equation may contaminate estimates for the growth equation. Regarding the use of IV for the trade share estimation, the $O_{t}$ coefficient in the growth equation loses its significance under SUR - though that in the investment equation remain broadly unchanged - which suggest the presence of a reverse-causation bias. In the remainder of this section we present in more detail the implications of narrowing the period of analysis to the second half of the century; widening the period length of the panel data to ten years; and changing the investment variable to include only machinery and equipment.

\subsection{Time coverage}

One key advantage of having a long-term data set covering the whole century is that we can compare the results with the second half of the century - the period examined by most cross-country growth studies - and assess the sensitivity of the coefficients. Regressions 2 and 3 show a moderately higher growth impact for investment and inflation volatility during 1950-2004. Regarding the openness role, there is little change in its negative direct association with $y_{t}$, but it loses significance in the investment equation during the second half so there is no evidence of trade-induced, investmentled growth. The result is consistent with the fact that the period was dominated by the ISI policies with a relatively high investment effort to the mid 1970s or so- followed by the poor investment record of the 1980s amid trade liberalisation. Once the positive openness contribution via investment is removed, the net openness growth effect is reduced to -0.06 , compared to -0.03 when the whole century is considered. Other changes worth highlighting are the loss of significance of illiteracy and a lower contribution to improvements in life expectancy during the period 1950-2004. This is not 
surprising, as most of the gains in both indicators were realised during the first half of the century.

We also run a regression based on the reduced form (from equation 3). Results are in regressions $16 a$ for the whole century and $16 b$ for the second half. In the former case, most of the other regressors keep their explanatory power (particularly those related to human capital and the volatility of the real exchange rate), while the openness variable looses its significance and has a positive sign. Meanwhile, in regression $16 b$ the positive contribution of human capital and the negative impact of macroeconomic instability are also maintained, and outcome broadly in line with that reported by De Gregorio (1992). But a difference to highlight is that in our regression for the period 1950-2004 the net negative growth contribution of $O_{t}$ remains, suggesting that the lack of a significant role for openness reported by De Gregorio may be related to the use of a single-equation specification - though he covers a larger sample of twelve countries including the LA-6.

\subsection{Period averages of panel data}

As noted before, a panel data set with a five-year period may have some advantages in capturing the impact of uncertainty on investment or of macroeconomic instability on economic growth, in addition to providing more observations, but it is subject to potential distortions caused by the business cycle. To address this potential shortcoming we also run regressions with a ten-year panel (12 to14) and compare with the outcome under five-years (regressions 1, 2 and 5). In particular, regressions 2 and 13 (estimated with 3SLS) show that investment has a stronger positive effect on growth per head when the length of the sub-periods is ten years $(0.21)$ compared to five years (0.13). In the former case, one standard deviation around $I_{t}$ has the potential to change productivity growth by $0.97 \%$ pts per year versus $0.72 \%$ pts when a five-year panel setting is used. The response to changes in life expectancy, however, weakens when the span is ten years and illiteracy loses its significance.

Both direct and indirect effects of openness on growth are also significant when using 10-year periods, with a smaller coefficient $(-0.11)$ for the direct effect compared to the values estimated under a five-year setting. The overall impact of one standard deviation below the average value of $O_{t}$ (i.e., a more closed economy) could have resulted in annual growth gains of $0.61 \%$ pts. The annual growth rate of the terms of trade shows a significant and negative correlation $(-0.05)$ under a ten-year aggregation. The coefficients associated with macroeconomic stability variables tend to lose significance. This is of little surprise, as GDP per head growth becomes less sensitive to the volatility variables when averaging out over a longer period.

\subsection{Investment variable}

The third sensitivity exercise looks at the implications of using series of equipment investment rather that the overall total. Because the expansion of productive capacity comes largely from accumulation of machinery and equipment, a stronger growth response is to be expected. Also, because a large part of equipment purchases is imported a likely finding is that trade affects growth especially via equipment invest- 
ment. ${ }^{33}$ However, these predictions are not supported by the outcome of regressions 4 when compared to the results obtained with total investment (regressions 2). The investment growth contribution is only marginally lower in the equipment case (0.12 vs. 0.13 for total investment), with the direct effect of openness remaining roughly the same - but with the level of significance down to $10 \%$. And the link between openness and investment is weaker under machinery and equipment ( 0.10 vs. 0.18$)$, suggesting that openness benefits overall investment proportionally more, for instance, by attracting larger foreign investment to develop infrastructure needed to exploit resource discoveries.

Another plausible prediction is that, to the extent that residential and infrastructure investment is less responsive to macroeconomic uncertainty, the role of the macro stability coefficients in accounting for investment and growth should be more prominent when the series of machinery and equipment are used. However, in general, results using the latter do not confirm this expectation. In fact, the coefficient of NBTTsd loses significance in regressions with machinery and equipment series.

Finally, this comparison can also give some insights into the contribution of public and private investment in long-term growth, with some studies reporting a lack of correlation when total investment is used and a positive link between public investment and macro economic volatility (e.g. Aizenman \& Marion, 1999). Available series of private investment for Brazil, Mexico and Venezuela show a strong correlation with those of investment in machinery and equipment, so that they can be used as a good proxy. Moreover, equipment investment is usually dominated by decisions in the private sector, though there was a substantial public investment to expand productive capacity during the ISI period in the LA-6. The lack of any major differences in the growth impact between the two cases (total and proxied private investment) suggests that there was a complementarity between public and private investment, with the public sector putting in place the infrastructure needed to support the expansion of economic activity, in addition to making possible improvements in life expectancy and education.

\footnotetext{
${ }^{33}$ According to our calculations, imports represented, on average, about $35 \%$ of total investment for the LA-6 during the period 1948-2004.
} 


\section{Conclusions}

This paper makes a contribution to the study of economic growth in developing countries by analysing the largest six Latin American economies over 105 years within a two-equation framework. The larger time span allows for a more appropriate quantification of long-term effects, while the departure from single-equation growth empirics makes it possible to be more explicit about the role of key determinants of economic growth and the effects emanating from the investment channel. The main drawback of going so far into the past is that, although results based on LA-6 are representative of Latin America as a whole, their use in explaining the experiences of the remaining countries is limited, particularly those with smaller economies. As a way of illustrating regional disparities, Astorga et al. (2005) show that, while there was considerable economic and social convergence between the LA-6 over the century - reflecting similar patterns of industrialisation, urbanization, and public provision - the smaller countries did not participate in this convergence process.

Confirming the findings of previous studies, the accumulation of investment - and its embodied technology - and human capital have been the principal source of growth in GDP per head during the twentieth century in our sample of countries. Moreover, the estimated coefficients of these variables are significant and robust to changes in estimation technique, specification and time aggregation. Our evidence indicates that, had the investment ratio in the LA- 6 been consistently $5.5 \%$ higher over the century, it would have resulted in an extra $1.2 \%$ pts of GDP per head growth per year. The welfare implications of this counterfactual are startling: the higher investment ratio would have resulted in a more than two-fold increase in real income for the average Latin American by 2000. Similarly, the unequivocal message is that trade openness is positively related to economic growth via the investment channel as more open economies are in a better position to exploit increasing returns to scale and to benefit from the embodied technology in capital goods imports. This evidence supports the case for trade-induced, investment-led growth.

More controversially, we found that, overall, openness is negatively correlated with economic growth, and that this is the result of the action of two effects: one with a positive indirect link, via investment, and one with an inverse connection operating directly on total factor productivity. ${ }^{34}$ This result is at odds with previous empirical work concentrating in the period 1960-1990 both on Latin America and on a wider sample of developing countries. But it is more in tune with findings of studies covering a longer time span. However, our evidence also indicates that the negative association may also be influenced by the action of forces related to resource endowments and changes in export diversification. Also, because our openness measure includes both policy and non-policy factors, this result in itself cannot be taken as evidence supporting protection. All in all, this outcome stresses the need for more research on the growth implications of trade integration in the region and, in particular, the role of policy barriers.

\footnotetext{
${ }^{34}$ The latter is consistent with the presence of learning externalities on infant industry grounds, but this is not definitively established by our analysis.
} 
The comparison between outcomes covering the whole twentieth century and those of the second half show a moderately stronger growth impact of investment and inflation volatility during the latter. Regarding the openness role, there is little change in its negative direct association with $y_{t}$, but it loses its significance in the investment equation during the second half. Equally, the convergence coefficient lacks significance when the period of analysis is reduced. These results confirm the importance of considering a longer time span to assess the contribution of the determinants of economic growth.

Another major concern of our research was to test for the growth consequences of macroeconomic volatility. Overall, the evidence suggests that an unstable and unpredictable macroeconomic environment has been a significant drag on growth and investment in the region. This is particularly the case with volatility in inflation, the terms of trade (via investment) and the real exchange rate. In contrast, our measures of fiscal policy and exchange rate premia proved not to be significant.

In facing the globalisation dilemma at the dawn of the new century, the assessment of the past century can offer some valuable lessons for Latin American and other developing countries. First, that capital accumulation (both public and private) is a necessary condition to boost long-term growth and improve standards of living, and that a more open economy can be instrumental in stimulating investment. Secondly, that despite significant advances in life expectancy and basic education, renewed efforts to strengthen the government's role in fostering human capital (particularly secondary education and research activity) remains a priority. Thirdly, that there is a need to secure macroeconomic stability to set the basis for high and sustained economic growth. This includes reinforcing fiscal and monetary discipline, a predictable real exchange rate, and a diversified export sector to minimise exposure to terms of trade fluctuations. 
Annex A: Detailed Econometric Outcome

\begin{tabular}{|c|c|c|c|c|c|c|c|c|c|c|}
\hline \multicolumn{11}{|c|}{ Table A1: Determinants of GDP per head growth } \\
\hline Panel setting & \multicolumn{10}{|c|}{ Five Years } \\
\hline Estimation method & \multicolumn{10}{|c|}{ Three Stage Least Squares (3SLS) } \\
\hline Specification info. & \multicolumn{2}{|c|}{ Core } & \multicolumn{4}{|c|}{ Augmented } & \multicolumn{2}{|c|}{ Equipment invest. } & \multicolumn{2}{|c|}{ Fixed-country effects } \\
\hline Equation & $\begin{array}{l}\text { (1a) } \\
\text { Growth }\end{array}$ & $\begin{array}{c}\text { (1)b) } \\
\text { investment }\end{array}$ & $\begin{array}{l}\text { (2a) } \\
\text { Growth }\end{array}$ & $\begin{array}{c}\text { (2b) } \\
\text { investment }\end{array}$ & $\begin{array}{c}\text { (3a) } \\
\text { Growth }\end{array}$ & $\begin{array}{c}\text { (3b) } \\
\text { investment }\end{array}$ & $\begin{array}{c}\text { (4a) } \\
\text { Growth }\end{array}$ & $\begin{array}{c}(\mathbf{4 b}) \\
\text { investment }\end{array}$ & $\begin{array}{l}\text { (5a) } \\
\text { Growth }\end{array}$ & $\begin{array}{c}\text { (5b) } \\
\text { investment }\end{array}$ \\
\hline Period & 190 & $0-2004$ & 190 & -2004 & & -2004 & 190 & 1-2004 & 190 & -2004 \\
\hline $\begin{array}{l}y_{t} \\
I_{t}\end{array}$ & $\begin{array}{c}\text { dep var } \\
\mathbf{0 . 1 4} \\
2.29\end{array}$ & dep var & $\begin{array}{c}\text { dep var } \\
\mathbf{0 . 1 3} \\
2.48\end{array}$ & dep var & $\begin{array}{c}\text { dep var } \\
\mathbf{0 . 1 5} \\
2.13\end{array}$ & dep var & $\begin{array}{c}\text { dep var } \\
\underline{\mathbf{0 . 1 2}} \\
1.78\end{array}$ & dep var & $\begin{array}{c}\text { dep var } \\
0.21 \\
3.84\end{array}$ & dep var \\
\hline Constant & 10.3 & -10.0 & 11.9 & 7.9 & 6.7 & 7.9 & 10.5 & 1.4 & 21.3 & 11.2 \\
\hline$o_{t}$ & $\begin{array}{l}-0.03 \\
-1.40\end{array}$ & $\begin{array}{l}0.22 \\
4.39\end{array}$ & $\begin{array}{l}-0.05 \\
-2.22\end{array}$ & $\begin{array}{l}0.18 \\
4.17\end{array}$ & $\begin{array}{l}-0.06 \\
-2.28\end{array}$ & $\begin{array}{l}0.01 \\
0.22\end{array}$ & $\frac{-0.05}{-1.86}$ & $\begin{array}{l}\mathbf{0 . 1 0} \\
3.57\end{array}$ & $\begin{array}{l}-0.06 \\
-2.53\end{array}$ & $\begin{array}{l}\mathbf{0 . 1 6} \\
3.80\end{array}$ \\
\hline$Y_{t 0}$ & $\begin{array}{c}-\mathbf{1 . 4} \\
-3.42\end{array}$ & $\begin{array}{c}2.3 \\
2.45\end{array}$ & $\begin{array}{c}-1.3 \\
-3.74\end{array}$ & & $\begin{array}{c}-0.8 \\
-1.34\end{array}$ & & $\begin{array}{c}-\mathbf{1 . 0} \\
-3.32\end{array}$ & & $\begin{array}{c}-2.6 \\
-5.89\end{array}$ & \\
\hline$t_{t-1}$ & & $\begin{array}{l}0.25 \\
2.90\end{array}$ & & $\begin{array}{l}0.32 \\
4.98\end{array}$ & & $\begin{array}{l}0.62 \\
9.78\end{array}$ & & $\begin{array}{l}0.58 \\
8.27\end{array}$ & & $\begin{array}{l}0.21 \\
3.22\end{array}$ \\
\hline$z_{t-1}$ & & & & $\begin{array}{l}\mathbf{0 . 7 8} \\
6.16\end{array}$ & & $\begin{array}{l}\mathbf{0 . 6 4} \\
5.54\end{array}$ & & $\begin{array}{l}0.22 \\
2.87\end{array}$ & & $\begin{array}{l}\mathbf{0 . 7 8} \\
6.57\end{array}$ \\
\hline d2life & $\begin{array}{l}1.01 \\
4.29\end{array}$ & & $\begin{array}{l}1.13 \\
5.40\end{array}$ & & $\begin{array}{l}0.86 \\
2.62\end{array}$ & & $\begin{array}{l}1.26 \\
6.28\end{array}$ & & $\begin{array}{l}\mathbf{1 . 1 5} \\
5.08\end{array}$ & \\
\hline lillit $_{t-2}$ & $\begin{array}{l}-0.41 \\
-1.28\end{array}$ & $\begin{array}{l}0.86 \\
1.09\end{array}$ & $\begin{array}{r}-0.70 \\
-2.47\end{array}$ & & $\begin{array}{l}-0.36 \\
-1.08\end{array}$ & & $\begin{array}{l}-0.60 \\
-2.13\end{array}$ & & $\begin{array}{l}-1.24 \\
-3.36\end{array}$ & \\
\hline$p_{t-1}$ & & $\begin{array}{l}0.65 \\
1.38\end{array}$ & & $\begin{array}{l}0.09 \\
0.22\end{array}$ & & $\begin{array}{l}-1.35 \\
-3.67\end{array}$ & & $\begin{array}{l}-0.09 \\
-0.39\end{array}$ & & $\begin{array}{l}0.50 \\
1.28\end{array}$ \\
\hline NBTTg & & & $\begin{array}{l}-0.02 \\
-0.99\end{array}$ & & $\begin{array}{l}-0.05 \\
-2.11\end{array}$ & & $\begin{array}{l}-0.02 \\
-0.95\end{array}$ & & $\begin{array}{l}0.004 \\
0.17\end{array}$ & \\
\hline ITTg & & & & $\begin{array}{l}\mathbf{0 . 1 1} \\
2.76\end{array}$ & & $\begin{array}{l}0.05 \\
1.35\end{array}$ & & $\frac{\mathbf{0 . 0 4}}{1.70}$ & & $\begin{array}{l}\mathbf{0 . 1 3} \\
3.53\end{array}$ \\
\hline US rirate & & & & $\begin{array}{l}-0.17 \\
-2.25\end{array}$ & & $\frac{-0.16}{-1.72}$ & & $\begin{array}{l}-0.05 \\
-1.15\end{array}$ & & $\begin{array}{l}-0.17 \\
-2.40\end{array}$ \\
\hline GBSHavg & & & $\begin{array}{l}0.06 \\
0.90\end{array}$ & & $\begin{array}{l}0.07 \\
1.02\end{array}$ & & $\begin{array}{l}0.03 \\
0.57\end{array}$ & & $\begin{array}{l}0.05 \\
0.68\end{array}$ & \\
\hline INFsd & & & $\frac{-0.01}{-1.89}$ & & $\begin{array}{l}-0.02 \\
-3.67\end{array}$ & & $\begin{array}{l}-0.01 \\
-1.96\end{array}$ & & $\begin{array}{l}-0.01 \\
-1.19\end{array}$ & \\
\hline NBTTsd & & & & $\begin{array}{r}-0.09 \\
-2.38\end{array}$ & & $\begin{array}{l}0.03 \\
0.93\end{array}$ & & $\begin{array}{l}-0.02 \\
-0.86\end{array}$ & & $\begin{array}{l}-0.10 \\
-2.75\end{array}$ \\
\hline REERsd & & & $\begin{array}{l}-0.04 \\
-3.17\end{array}$ & $\begin{array}{l}-0.04 \\
-1.18\end{array}$ & $\begin{array}{l}-0.04 \\
-2.42\end{array}$ & $\frac{-0.04}{-1.84}$ & $\begin{array}{l}-0.05 \\
-3.76\end{array}$ & $\begin{array}{l}-0.02 \\
-1.26\end{array}$ & $\begin{array}{l}-0.05 \\
-3.25\end{array}$ & $\begin{array}{l}-0.05 \\
-1.59\end{array}$ \\
\hline & & & & & & & & & & \\
\hline $\begin{array}{l}\text { MKratio }_{t-1} \\
\text { d2agri }\end{array}$ & & & & & & & & & & \\
\hline wWI & -2.5 & & -2.2 & & & & -1.8 & & -2.9 & \\
\hline $\begin{array}{l}\text { WWII } \\
\text { DEBT80 }\end{array}$ & -3.4 & 4.2 & -3.3 & -6.3 & -3.6 & -6.8 & -3.3 & -3.1 & -3.0 & -6.6 \\
\hline Adjusted-R2 & 0.66 & 0.43 & 0.72 & 0.56 & 0.63 & 0.75 & 0.72 & 0.58 & 0.67 & 0.60 \\
\hline S.E. of regression & 1.58 & 4.16 & 1.43 & 3.64 & 1.32 & 1.91 & 1.44 & 2.18 & 1.59 & 3.47 \\
\hline Serial correlation ${ }^{1}$ & 0.11 & 0.18 & 0.08 & 0.17 & 0.13 & 0.10 & 0.04 & 0.13 & 0.01 & 0.16 \\
\hline Observations & & 120 & & 20 & & 6 & & 20 & & 20 \\
\hline $\begin{array}{l}\text { t-statistics are in itall } \\
\text { Country-specific dum } \\
\text { (1) Measured by the }\end{array}$ & $\begin{array}{l}\text { s. In bol } \\
\text { nies inclu } \\
\text { rst-order }\end{array}$ & $\begin{array}{l}\text { led: the Mexi } \\
\text { utocorrelation }\end{array}$ & $\begin{array}{l}\text { significa } \\
\text { n revolutic } \\
\text { pefficient }\end{array}$ & $\begin{array}{l}\text { at at the } 5 \% \\
\text { n years; Ven } \\
\text { of the residual }\end{array}$ & 1, and & $\begin{array}{l}\text { old unde } \\
\text { azil in } 19\end{array}$ & 4 at $10^{\circ}$ & & & \\
\hline
\end{tabular}




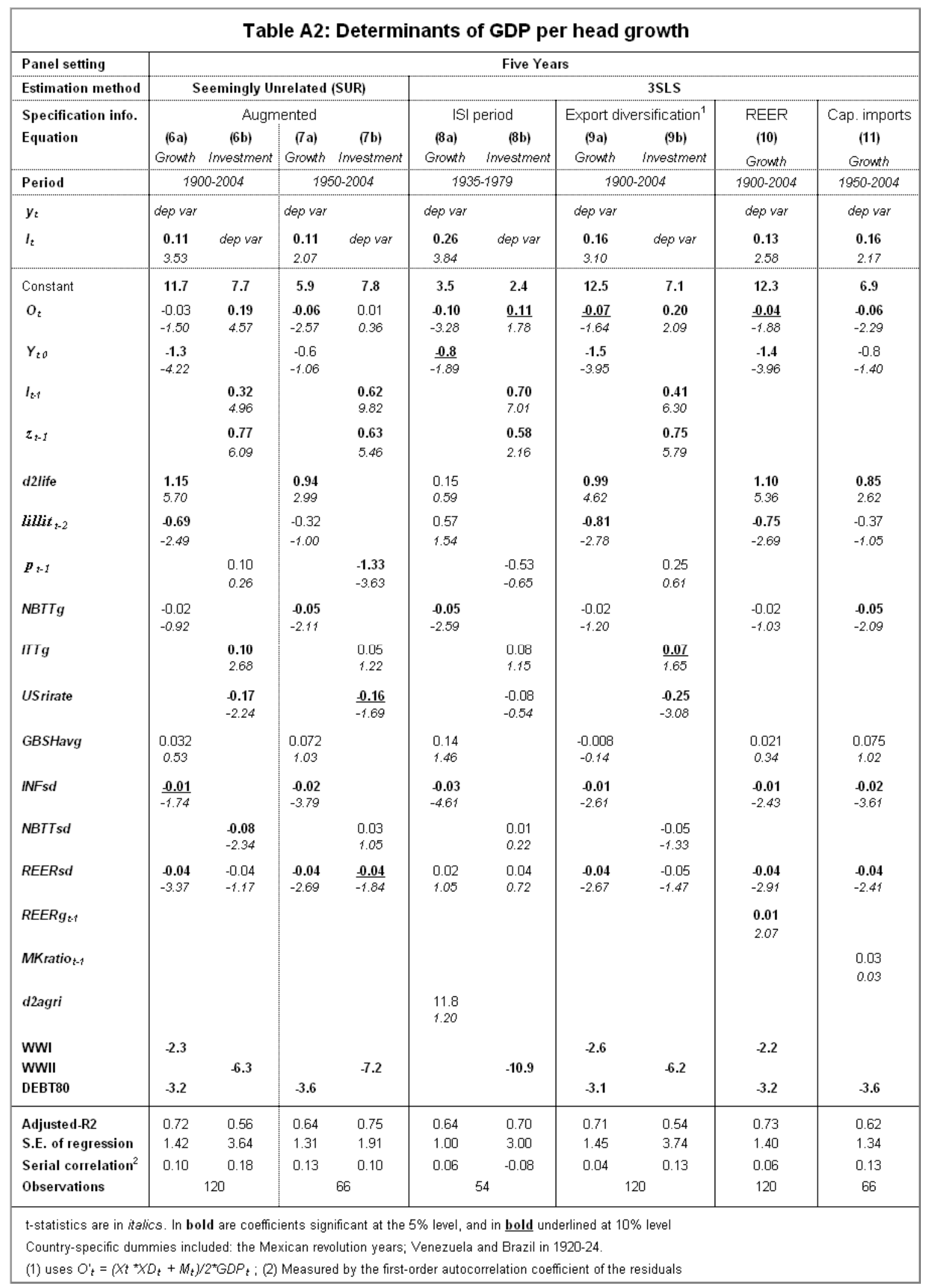


Table A3: Determinants of GDP per head growth

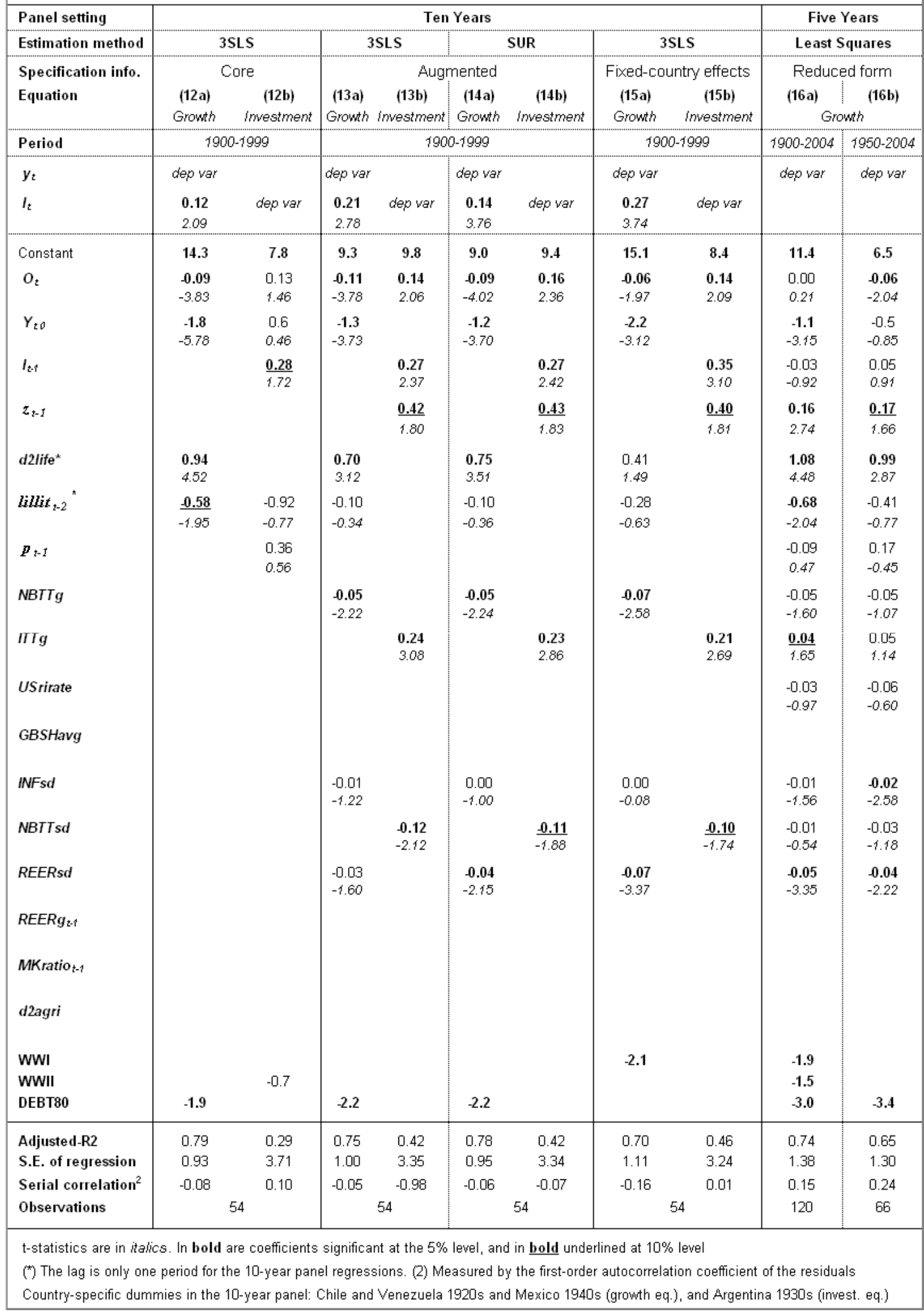




\section{Annex B: Data Sources}

The source is OxLAD, unless otherwise indicated.

Average tariffs. Coatsworth and Williamson (2002) data set for Argentina, Brazil, Colombia and Mexico up to 1950. Díaz et al. (2005) for Chile; own calculations for Venezuela (based on OxLAD data).

Capital imports share. OxLAD up to 2000; thereafter uses ECLAC data. The imported component of investment $(M K)$ is calculated by applying the import share of capital goods to total imports at constant prices. The ratio of imported to domestically produced investment (MKratio) is then obtained as MK/(Investment$M K)$.

Export diversification index. Own calculations using data for export-commodity composition from Mitchell (1993) up to 1988; ECLAC thereafter.

Exchange rate premia. Reinhart and Rogoff (2004) after 1950. Prior to 1950 own calculations from nominal exchange rate data in Astorga (2007).

Global freight real costs index. Mohammed and Williamson (2004, Table 3).

Net barter terms of trade. Brazil: IBGE (2003); Chile: Díaz et al. (2005); Colombia: OxLAD to 1992 and ECLAC thereafter.

Openness. The procedure to construct the trade ratio is as follows: $(i)$ applies growth rates of export and import quantum indices to exports and imports dollar values in 1970; (ii) applies growth rates of GDP series at constant prices to the GDP dollar value in 1970; (iii) adds up the resulting export and import series and divide them by the GDP series.

Export quantum. Brazil: IBGE (2003); Chile: Díaz et al. (2005); Mexico: the revolution gap is filled in with values of the series of export of goods at constant dollars (export values deflated by the unit value of exports).

Import quantum. Argentina: before 1910 figures are calculated from import series at constant dollars. Brazil: IBGE (2003); Chile: Díaz et al. (2005); Colombia: GRECO (2002) for 1905 onwards. Before 1905 uses imports at constant dollars. Venezuela: from 1920 onwards uses an index based on imports from national accounts at 1968 prices (Baptista, 1997). Prior to 1920 uses import series at constant dollars.

Investment. (i) in machinery and equipment. Hofman (2000) to 1994, thereafter completed from official sources. (ii) Private investment and investment deflators. Brazil IBGE (2003); Venezuela: Baptista (1997). Mexico: only private investment calculated as a residual from total and public investment series from ITAM (2004).

Real effective exchange rate. Astorga (2007).

Real interest rates. Argentina: Veganzones and Winograd (1997); Colombia GRECO (2002); US: rates in 1900-1913 refer to call money rates; in 1914-1954 to discount rates reported by the Federal Reserve Bank of New York; in 1955-2005 to the federal funds rates. Nominal values are deflated by the US producer price index. 


\section{References}

Aizenman, J. and N. Marion (1999). Volatility and investment: interpreting evidence from developing countries. Economica, 66(262), 157-79.

Andrés J. and I. Hernando (1997). Does inflation harm economic growth? evidence for the OECD. NBER Working Papers 6062, National Bureau of Economic Research.

Astorga, P. (2007). Real exchange rates in Latin America: what does the $20^{\text {th }}$ century reveal? DHEI, Working Papers in Economic History 2007-03. Universidad Carlos III.

Astorga, P, A.R. Bergés, and E.V.K. FitzGerald (2005). The standard of living in Latin America over the twentieth century. Economic History Review, 58(4), 765796.

Astorga, P., A.R. Bergés, and E.V.K. Fitzgerald (2003). Productivity growth in Latin America during the twentieth century. Discussion Papers in Economic and Social History 51. Nuffield College, Oxford University.

Baldwin, R. and E. Seghezza (1996). Trade-induced investment-led growth. CEPR Discussion Papers 1420.

Baptista, A. (1997). Bases Cuantitativas de la Economía Venezolana, 1830-1995. Ediciones Fundación Polar: Caracas.

Barro, R.J. and X. Sala-i-Martin (1995). Economic Growth. McGraw-Hill: New York.

Birdsall, N. and A. Hamoudi (2002). Commodity dependence, trade, and growth: when 'openness' is not enough. Center for Global Development Working Paper 7.

Bosworth B.P. and S.M. Collins (2003). The empirics of growth: an update. Brookings Papers on Economic Activity, 34(2003-2), 113-206.

Bruno, M. and W. Easterly (1998). Inflation crises and long-run growth. Journal of Monetary Economics, Elsevier, 41(1), 3-26.

Caballero, R.J. (1991). On the sign of the investment-uncertainty relationship. American Economic Review, 81(1), 279-88.

Corden, W.M.(1974). Trade Policy and Economic Welfare. Oxford University Press: Oxford.

Corden, W.M.and J.P. Neary (1982). Booming sector and de-industrialisation in an small open economy, Economic Journal, 92, 825-48.

Coatsworth J.H. and J.G. Williamson (2002). The roots of Latin American protectionism: looking before the Great Depression. NBER Working Paper No. 8999.

De Gregorio, J. (1992). Economic growth in Latin America. Journal of Development Economics, 39(1), 59-84.

Díaz, J., R. Lüders, and G. Wagner (2005). Chile 1820-2000: La República en Cifras, Santiago, Chile. 
Dixit, A.K. and R.S. Pindyck (1994). Investment under Uncertainty, University Press: Princeton.

Economic Commission for Latin America and the Caribbean, ECLAC, (various years). Statistical Yearbook for Latin America (SYLA). New York, NY: UN.

Frankel, J.A. and D. Romer (1999). Does trade cause growth? American Economic Review, American Economic Association, 89(3), 379-399.

Grossman, G.M. and E. Helpman (1990). Trade, innovation, and growth. American Economic Review, 80(2), 86-91.

Grupo de Estudios del Crecimiento Económico, GRECO, (2002). El Crecimiento Económico Colombiano en el Siglo XX. Banco de la República - Fondo de Cultura Económica: Bogotá.

Harrison, A. (1996). Openness and growth: a time-series, cross-country analysis for developing countries. Journal of Development Economics, 48(2), 419-447.

Hofman, A. (2000). The Economic Development of Latin America in the Twentieth Century. Edward Elgar Publishing: Northampton, MA.

Instituto Brasileiro de Geografía e Estadística, IBGE, (2003). Estatísticas do Século $X X$. Rio de Janeiro: IBGE. In: http://www.ibge.gov.br/seculoxx/default.shtm

Instituto de Pesquisa Econômica Aplicada (IPEA). IPEA Data. Available from: http://www.ipeadata.gov.br/ipeaweb.dll/ipeadata?598502812

Instituto Tecnológico Autónomo de México, ITAM, (2004). Estadísticas Históricas de México. Available from: http://biblioteca.itam.mx/recursos/ehm.html\#sector

Katz J. and B. Kosacoff (2000). Technological learning, institution building and the microeconomics of import substitution. In: Cárdenas, E.; J.A. Ocampo and R. Thorp, eds., (2000). An Economic History of Twentieth Century Latin America, 3 vol. 2. New York-Oxford, Palgrave \& St. Antony's College, 36-57.

Lee, J.W.(1995). Capital goods imports and long-run growth. Journal of Development Economics, 48(1), 91-110.

Maddison, A. (2001). The World Economy: A Millennial Perspective, Development Centre of the OECD: Paris.

Mitchell, B.R. (1993). International Historical Statistics: The Americas, 1750-1988. Macmillan: Basingstoke.

Mohammed, S.I.S. and J.G.Williamson (2004). Freight rates and productivity gains in British tramp shipping 1869-1950. Explorations in Economic History, 41-3, 172203.

Pritchett, L. and G. Sethi (1994). Tariff rates, tariff revenue, and tariff reform: some new facts. The World Bank Economic Review; 8 (1), 1-16.

O'Rourke, K.H. (2000). Tariffs and growth in the late 19th century. The Economic Journal,110-463, 456-483. 
Oxford Latin American Economic History Database, OxLAD. The Latin American Centre, Oxford University. Available from: http://oxlad.qeh.ox.ac.uk/

Reinhart, C.M., and K.S. Rogoff. (2004). The modern history of exchange rate arrangements: a reinterpretation. The Quarterly Journal of Economics, 119(1), 148.

Rodríguez, F. (2006). Openness and growth: what have we learned? Wesleyan Economics Working Papers 2006-011, Wesleyan University.

Rodríguez, F. and D. Rodrik (2001). Trade Policy and Economic Growth: A Skeptic's Guide to the Cross-National Evidence. In: B. Bernanke and K. Rogoff NBER Macroeconomics Annual 2000, National Bureau of Economic Research Cambridge, MA.

Sachs, J.D. and A.M. Warner (1997). Fundamental sources of long-run growth. American Economic Review, 87(2), 184-88.

Servén, L. (2003). Real-exchange-rate uncertainty and private investment in LDCs. The Review of Economics and Statistics, 85(2), 492-492.

Stasavage, D. (2000). Private investment and political uncertainty. STICERD - Development Economics Papers 25, Suntory and Toyota International Centres for Economics and Related Disciplines, LSE.

Taylor, A.M. (1998). On the cost of inward-looking development: price distortions, growth, and divergence in Latin America. Journal of Economic History; 58; 1-28.

Thorp, R. (1998). Progress, Poverty and Exclusion: An Economic History of Latin America in the 20th Century, Baltimore, MD: Inter-American Development Bank, distributed by John Hopkins University Press.

Vamvakidis, A. (2002). How robust is the growth-openness connection? historical evidence. Journal of Economic Growth, 7(1), 57-80.

Veganzones, M-A., and C. Winograd (1997). Argentina in the 20th Century: An Account of Long-Awaited Growth. Development Centre of the OECD: Paris. Dataset in:

http://www.oecd.org/findDocument/0,2350,en_2649_33987_1_119699_1_2_1,00. $\underline{\mathrm{html}}$

Wacziarg, R. (2001). Measuring the dynamic gains from trade. Policy Research Working Paper Series, The World Bank.

Yanikkaya H. (2003). Trade openness and economic growth: a cross-country empirical investigation. Journal of Development Economics; 72(1); 57-89. 


\section{University of Oxford Discussion Papers in Economic and Social History: Recent publications}

60 Avner Offer, The Markup For Lemons: Quality And Uncertainty in American and British Used-Car Markets c.1953-1973 (September 2005; reprinted with revisions June 2007)

61 Natalia Mora-Sitja, Exploring Changes in Earnings Inequality during Industrialization: Barcelona, 1856-1905 (April 2006)

62 Camilla Brautaset and Regina Grafe, The Quiet Transport Revolution: Returns to Scale, Scope and Network Density in Norway's Nineteenth-Century Sailing Fleet (June 2006)

63 Mohammad Niaz Asadullah, Educational Disparity in East and West Pakistan, 1947-71: Was East Pakistan Discriminated Against? (July 2006)

64 Jane Humphries, 'Because they are too menny...' Children, Mothers, and Fertility Decline: The Evidence from Working-Class Autobiographies of the Eighteenth and Nineteenth Centuries (September 2006)

65 M. A. Irigoin and R. Grafe, Bargaining for Absolutism: A Spanish Path to Nation State and Empire Building (November 2006)

66 Jane Humphries and Tim Leunig, Cities, market integration and going to sea: stunting and the standard of living in early nineteenth-century England and Wales (March 2007)

67 Paul Sharp and Jacob Weisdorf, From Preventive to Permissive Checks: The Changing Nature of The Malthusian Relationship between Nuptiality and the Price of Provisions in the Nineteenth Century (November 2007)

68 Roman Studer, India and the Great Divergence: Assessing the Efficiency of Grain Markets in Eighteenth- and Nineteenth-Century India (November 2007)

69 Guillaume Daudin, Domestic Trade and Market Size in Late Eighteenth-Century France (April 2008)

70 Avner Offer, Charles Feinstein (1932-2005) and British Historical National Accounts (June 2008)

71 Sandra González-Bailón and Tommy Murphy, When Smaller Families Look Contagious: A Spatial Look at the French Fertility Decline Using an Agent-based Simulation Model (September 2008)

72 Luke Samy, The Building Society Promise: Building Societies and Home Ownership, c1880-1913 (October 2008)

73. Leigh A. Gardner, To Take or to Make? Contracting for Legitimacy in the Emerging States of Twelfth-Century Britain (November 2008)

74. Avner Offer, British Manual Workers: From Producers to Consumers, c.1950-2000 (December 2008)

75 Pablo Astorga, A Century of Economic Growth in Latin America (January 2009) 
UNIVERSITY OF OXFORD DISCUSSION PAPERS IN ECONOMIC AND SOCIAL HISTORY are edited by

Rui Esteves (Brasenose College, Oxford, OX1 4AJ) Leigh Gardner (Jesus College, Oxford, OX1 3DW)

Papers may be downloaded from http://www.nuff.ox.ac.uk/Economics/History 